\title{
Icelandic volcanic dust can have a significant influence on the cryosphere in Greenland and elsewhere
}

\author{
Outi Meinander, ${ }^{1}$ Pavla Dagsson-Waldhauserova ${ }^{2,3,4,5}$ \& Olafur Arnalds ${ }^{2}$ \\ 1 Finnish Meteorological Institute, Research and Development, Climate Research, Erik Palmenin aukio 1, Fl-00560 Helsinki, Finland \\ 2 Faculty of Environmental Sciences, Agricultural University of Iceland, Hvanneyri, IS-311 Borgarnes, Iceland \\ ${ }^{3}$ Institute of Earth Sciences, University of Iceland, Saemundargata 2, IS-101 Reykjavik, Iceland \\ ${ }^{4}$ Faculty of Environmental Sciences, Czech University of Life Sciences Prague, Kamycka 961/129, CZ-165 21 Praha 6-Suchdol, Czech Republic \\ ${ }^{5}$ Faculty of Physical Sciences, University of Iceland, Saemundargata 2, IS-101 Reykjavik, Iceland
}

The melting and darkening of Greenland Ice Sheet (GrIS) has recently been of major concern (Benning et al. 2014; Dumont et al. 2014; Polashenski 2015; Tedesco et al. 2015). Dumont et al. (2014) suggested that the springtime darkening of the GrIS, which has been observed since 2009, is due to an increased load of light-absorbing impurities (LAIs) in snow that consist of soot or dust and, potentially, microorganisms. Benning et al. (2014) argued that microorganisms, such as the pigmented algae that reside in snow and ice, can cause a substantial reduction in albedo. They also hypothesized that as the climate warms and melt seasons become longer, biological habitats could expand and increasingly contribute to the darkening. Tedesco et al. (2015) stated that despite the crucial impact of albedo in energy balance, the roles of the different processes driving it have yet to be identified. They pointed out that cryoconite (a mixture of dust, pebbles, soot and microbes) and pigmented algae can reduce albedo. Early observations of cryoconite in Greenland snow and ice were made by the Finnish explorer Adolf Erik Nordenskiöld (1883).

More recently, Polashenski et al. (2015) showed that satellite data analysis of Moderate Resolution Imaging Spectrometer (MODIS) surface reflectance from uncorrected Terra sensor degradation has important contributions for detecting Greenland's dry snow zone albedo decline. They did not find that enhanced deposition of LAIs caused significant dry snow albedo reduction or melt events, but they acknowledged prior work on GrIS, wherein the impact of MODIS Terra degradation had been concluded as insignificant. Polashenski et al. (2015) agreed that part of the dry snow zone albedo decline could be real.

We argue that the transport and deposit of lightabsorbing Icelandic volcanic dust can have a significant influence in the cryosphere, in Greenland and elsewhere, and that this effect must be addressed in order to

\section{Correspondence}

Outi Meinander, Finnish Meteorological Institute, Research and Development, Climate Research, Erik Palmenin aukio 1, Fl-00560 Helsinki, Finland. E-mail: Outi.Meinander@fmi.fi constrain glacier and ice cap melt rates and confront the causes of deglaciation.

Iceland is the most important Arctic dust source and the largest of the Arctic deserts (Arnalds et al. 2016). Icelandic volcanic dust can be transported over the North Atlantic to Europe and Greenland (Prospero et al. 2012). Icelandic dust-storm frequency has been estimated to be up to 135 dust days per year. About half of the annual dust events in the southern part of Iceland take place in winter at sub-zero temperatures, when dust mixes with snow (Dagsson-Waldhauserova et al. 2015). The fertilizing effect of dust (Arnalds et al. 2014) can offer an important nutrient source that enables microorganisms to grow. Other living organisms present in Icelandic dust can also be intercontinentally transported. The particle-cryosphere interaction is controlled by the particle properties, which vary according to the origin from the seven major Icelandic dust sources (Arnalds et al. 2016). While hydrophilic particles can be washed down with melt water (Doherty et al. 2013), hydrophobic particles can concentrate on the surface, and play a role in creating environmental conditions within snow/ice that favour the existence of microorganisms.

Assessments of the effect of Icelandic volcanic dust on snow/ice surface darkening and melt in the Greenland cryosphere-and elsewhere-are lacking. We hypothesize that, in the Arctic, Icelandic dust may have a comparable or even larger effect on the cryosphere than soot (Bond et al. 2013). Observations of, and modelling results bearing on, Icelandic dust and cryosphere interactions for the past, present and future are urgently needed.

\section{References}

Arnalds O., Dagsson-Waldhauserova P. \& Olafsson H. 2016. The Icelandic volcanic aeolian environment: processes and impacts-a review. Aeolian Research 20, 176-195.

Arnalds O., Olafsson H. \& Dagsson-Waldhauserova P. 2014. Quantification of iron-rich volcanogenic dust emissions and 
deposition over the ocean from Icelandic dust sources. Biogeosciences 11, 6623-6632.

Benning L.G., Anesio A.M., Lutz S. \& Tranter M. 2014. Biological impact on Greenland's albedo. Nature Geoscience 7, 691 .

Bond T.C., Doherty S.J., Fahey D.W., Forster P.M., Berntsen T., DeAngelo B.J., Flanner M.G., Ghan S., Kärcher B., Koch D., Kinne S., Kondo Y., Quinn P.K., Sarofim M.C., Schultz M.G., Schulz M., Venkataraman C., Zhang H., Zhang S., Bellouin N., Guttikunda S.K., Hopke P.K., Jacobson M.Z., Kaiser J.W., Klimont Z., Lohmann U., Schwarz J.P., Shindell D., Storelvmo T., Warren S.G. \& Zender C.S. 2013. Bounding the role of black carbon in the climate system: a scientific assessment. Journal of Geophysical Research-Atmospheres 118, 5380-5552.

Dagsson-Waldhauserova P., Arnalds O., Olafsson H., Hladil J., Skala R., Navratil T., Chadimova L. \& Meinander O. 2015. Snow-dust storm: unique case study from Iceland, 6-7 March 2013. Aeolian Research 16, 69-74.

Doherty S.J., Grenfell T.C., Forsström S., Hegg D.L., Brandt R.E. \& Warren S.G. 2013. Observed vertical redistribution of black carbon and other insoluble light-absorbing particles in melting snow. Journal of Geophysical Research-Atmospheres 118, 5553-5569.

Dumont M., Brun E., Picard G., Michou M., Libois Q., Petit J.-R., Geyer M., Morin S. \& Josse B. 2014. Contribution of lightabsorbing impurities in snow to Greenland's darkening since 2009. Nature Geoscience 7, 509-512.

Nordenskiöld A.E. 1883. Nordenskiöld on the inland ice of Greenland. Science 2(44), 732-738.

Polashenski C.M., Dibb J.E., Flanner M.G., Chen J.Y., Courville Z.R., Lai A.M., Schauer J.J., Shafer M.M. \& Bergin M. 2015. Neither dust nor black carbon causing apparent albedo decline in Greenland's dry snow zone: implications for MODIS C5 surface reflectance. Geophysical Research Letters 42, 9319-9327.

Prospero J.M., Bullard J.E. \& Hodgkins R. 2012. High-latitude dust over the North Atlantic: inputs from Icelandic proglacial dust storms. Science 335, 1078-1082.

Tedesco M., Doherty S., Warren W., Tranter M., Stroeve J., Fettweis X. \& Alexander P. 2015. What darkens the Greenland Ice Sheet? Eos, Transactions of the American Geophysical Union 96, doi: http://dx.doi.org/10.1029/2015EO035773 